\title{
Racism, Feminism and Language in Zora Neale Hurston's Their Eyes Were Watching God
}

\author{
Sawsan Qashgari \\ Department of Foreign Languages \\ Taif University, Saudi Arabia
}

\begin{abstract}
Their Eyes Were Watching God by Zora Neale Hurston has received mixed reviews over Hurston's treatment of African Americans' struggle. Her African American male contemporaries saw her novel as an oversimplification of racial issues. Nevertheless, a closer reading of her book proves otherwise. This paper explores her powerful, albeit subtle, portrayal of the desperation imposed not only on her race, but on her gender as well. Hurston masterfully represents racial and gender issues without resorting to the anger and hostility that appear in the works of most of her contemporary African American male writers such as Richard Wright. Hurston's characterization of the female protagonist, her skin-color, and even the language she uses, allows her to draw an accurate image of the African American woman in the early 1900s. Her choice of the African American dialect grants Janie Crawford a voice of her own despite society's constant attempts to silence her. Focusing on the context and Hurston's narrative and language, this paper aims at asserting that Their Eyes Were Watching God is not merely a tragic love story; it is a skilful representation of race, gender and class issues in America at that period of time.
\end{abstract}

Key Words: Hurston, female voice, racial conflicts, African American dialect, African American women, gender oppression

Cite as: Qashgari, S. (2017). Racism, Feminism and Language in Zora Neale Hurston's Their Eyes Were Watching God. Arab World English Journal for Translation \& Literary Studies, 1(2). DOI:http://dx.doi.org/10.24093/awejtls/vol1no2.3 